$D(-)$ - $\beta$-hydroxybutyrate: acetoacetate ratios reported in the present paper (Table 5) indicate that in incubated liver slices from well-fed rats the $\mathrm{NAD}: \mathrm{NADH}_{2}$ ratio within the mitochondria is lower than in slices from starved rats. Some support for this conclusion is provided by the observation of Frunder \& Richter (1955) and Kayne, Taylor \& Alpert (1963) that during incubation the $\mathrm{NAD}: \mathrm{NADH}_{\mathbf{2}}$ ratio increases more rapidly in liver slices from starved rats or rats given a lowcarbohydrate diet than in liver slices from rats given a balanced diet.

Calcium ions increase the $D(-)$ - $\beta$-hydroxybutyrate : acetoacetate ratio (and presumably therefore decrease the $\mathrm{NAD}: \mathrm{NADH}_{2}$ ratio) (Table 5), but there seems to be no correlation between this effect and the effects of $\mathrm{Ca}^{2+}$ ions on total ketonebody production.

\section{SUMMARY}

1. Calcium ions decrease the total amount of ketone bodies formed by liver slices from fed rats, but increase the total formed by liver slices from starved rats and rats given a low-carbohydrate diet.

2. Calcium ions enhance ketone-body production by liver slices from fed and starved rats in the presence of octanoate, but the effect is more marked with starved animals. In contrast, $\mathrm{Ca}^{2+}$ ions depress the formation of ketone bodies from both fed and starved animals when pyruvate is the substrate.

3. The ratio of $D(-)$ - $\beta$-hydroxybutyrate to acetoacetate formed is increased by $\mathrm{Ca}^{2+}$ ions (about threefold); the value for the ratio is higher in liver slices from fed animals than in liver slices from starved animals.

4. Leakage of protein from rat-liver slices during the incubation is lower in the presence of $\mathrm{Ca}^{2+}$ ions.

We thank Professor Sir Hans A. Krebs, F.R.S., for useful discussions and advice in the preparation of this paper. J.M. was supported by a Medical Research Council scholarship. This work was aided by grants from the Rockefeller Foundation and from the National Institutes of Health, United States Public Health Service.

\section{REFERENCES}

Bondy, P. K. \& Wilhelmi, A. E. (1950). J. biol. Chem. 186, 245.

Cutting, M. \& McCance, R. A. (1947). J. Physiol. 106, 405. Frunder, H. \& Richter, G. (1955). Hoppe-Seyl. Z. 299, 39. Gore, M. B. R. \& McIlwain, H. (1952). J. Physiol. 117, 471. Hohorst, H. J., Kreutz, F. H. \& Bücher, Th. (1959). Biochem. Z. 332, 18.

Hohorst, H. J., Kreutz, F. H. \& Reim, M. (1961). Biochem. biophys. Res. Commun. 4, 1959.

Kaufmann, E. \& Wertheimer, E. (1957). Amer. J. Physiol. $190,133$.

Kayne, H. L., Taylor, N. \& Alpert, N. R. (1963). Arch. Biochem. Biophys. 100, 13.

Krebs, H. A., Mellanby, J. \& Williamson, D. H. (1962). Biochem. J. 82, 96.

Lasnitzki, A. (1934). Protoplasma, 22, 274.

Layne, E. (1957). In Methods in Enzymology, vol. 3, p. 447. Ed. by Colowick, S. P. \& Kaplan, N. O. New York: Academic Press Inc.

Robertson, W. v. B. (1942). Science, 96, 93.

Robinson, J. R. (1949). Biochem. J. 45, 68.

Wieland, O., Matschinsky, F., Löffler, G. \& Müller, U. (1961). Biochem. biophys. Acta, 53, 412.

Williamson, D. H., Mellanby, J. \& Krebs, H. A. (1962). Biochem. J. 82, 90.

Biochem. J. (1963) 88, 444

\title{
Studies on the Metabolism of the Protozoa
}

\section{THE MOLECULAR STRUCTURE OF THE RESERVE POLYSACCHARIDES FROM OCHROMONAS MALHAMENSIS AND PERANEMA TRICHOPHORUM*}

\author{
By A. R. ARCHIBALD, W. L. CUNNINGHAM, D. J. MANNERS AND J. R. STARK \\ Department of Chemistry, University of Edinburgh
}

AND J. F. RYLEY

Imperial Chemical Industries Ltd., Pharmaceuticals Division, Alderley Park, Macclesfield, Cheshire

(Received 27 February 1963)

Although several protozoa synthesize iodophilic reserve polysaccharides of the glycogen, amylopectin or starch type (see, for example, Manners \&

$$
\text { * Part 9: Ryley (1962). }
$$

Ryley, 1955; Archibald, Hirst, Manners \& Ryley, 1960), others contain iodophobic reserve substances. We now describe the structural analysis of such materials from the flagellated protozoa Ochromonas malhamensis and Peranema tricho- 
phorum. The former is referred to as 'leucosin', even though this term has been incorrectly applied to the starch-type polysaccharide from Chilomonas paramecium (Hutner \& Provasoli, 1951), and the latter as 'paramylon' (also known as paramylum).

$O$. malhamensis is a freshwater organism with two unequal flagellae, belonging to the order Chrysomonadina, a group whose members characteristically store oil and leucosin; the former occurs as droplets scattered throughout the cytoplasm, and leucosin accumulates in a posterior vacuole, which may be so large as to almost fill the cell. The organism, about $6 \mu \times 10 \mu$ in size, is phagotrophic, i.e. can ingest particulate food, and, although it has a golden-brown chromatophore, it can only partially meet its needs by photosynthesis. In pure cultures, carbon requirements are satisfied by sugars, but not by acetate. $P$. trichophorum is a colourless member of the order Euglenoidina. It lives in ponds rich in organic matter, and feeds phagotrophically on a variety of plant and animal food, e.g. other protozoa such as Ochromonas. It is an elongate organism, approximately $55 \mu \times 22 \mu$ in size in culture, that can move either by swimming or gliding; it has a stout flagellum about as long as the body projecting anteriorally, and another more delicate flagellum extending spirally backwards adherent to the pellicle. Paramylon is stored in the form of flat granules about 3.4 $\mu$ diam. $\times 2.3 \mu$ thick. Excellent descriptions of the structure and biology of these two organisms are given by Pringsheim (1952) and Chen (1950).

In preliminary accounts of this work (Archibald, Manners \& Ryley, 1958; Cunningham, Manners \& Ryley, 1961), evidence for the presence of $\beta-(1 \rightarrow 3)$ glucosidic linkages in both polysaccharides was described. The same type of linkage has also been found in the reserve polysaccharides from the protozoa Euglena gracilis (Clarke \& Stone, 1960) and Astasia ocellata (D. J. Manners, J. F. Ryley \& J. R. Stark, unpublished work).

\section{MATERIALS AND METHODS}

\section{Materials}

Ochromonas malhamensis was grown in daylight (not essential) at $28^{\circ}$ in a medium containing $0.1 \%$ of Oxoid peptone, $0 \cdot 1 \%$ of Hepamino liver extract (Evans Medical Ltd., Speke, Liverpool 24) and $0.1 \%$ of glucose at pH $6.0 ; 2$ l. flasks containing 1.51 . of medium were used for bulk growth. Cells from $15 \mathrm{l}$. of culture fluid were harvested by centrifuging after 6 days of growth, suspended in $120 \mathrm{ml}$. of culture fluid, heated at $100^{\circ}$ for $10 \mathrm{~min}$. and centrifuged while hot. The residue was twice extracted with $150 \mathrm{ml}$. of water at $100^{\circ}$ for $10 \mathrm{~min}$. and centrifuged while still hot. The three extracts were treated with ethanol ( 2 vol.) and allowed to stand overnight. The precipitates from six such batches of medium were combined and used for leucosin preparations I and II.
From a further $75 \mathrm{l}$. of culture fluid, polysaccharide material was obtained in a similar way, and from it leucosin preparation III was isolated.

Peranema trichophorum was grown in daylight (not essential) at $20^{\circ}$ in a medium containing $10 \%(v / v)$ of soil extract and $2 \%(v / v)$ of milk at $\mathrm{pH} 7 \cdot 0$. The soil extract was prepared by autoclaving garden soil with an equal weight of water at $15 \mathrm{lb}$./in. ${ }^{2}$ for $20 \mathrm{~min}$., allowing it to settle and centrifuging the supernatant to clarify it. The complete medium was sterilized by steaming for $30 \mathrm{~min}$. on 3 consecutive days for small quantities, but for bulk growth 21 . conical flasks containing $1 \cdot 5 \mathrm{l}$. of $10 \%(\mathrm{v} / \mathrm{v})$ soil extract were sterilized by autoclaving, and the required quantity $(30 \mathrm{ml}$.) of milk, previously sterilized by steaming, was added together with the inoculum. Stock cultures were carried in $10 \mathrm{ml}$. quantities of medium in tubes, being subcultured every 2 weeks. For bulk growth, $250 \mathrm{ml}$. amounts of medium were inoculated with 1 tube of culture, and, 2 weeks later, one such flask was used to inoculate a 21. flask. Organisms were grown in $54 \mathrm{l}$. batches of medium, harvested by centrifuging after 4 weeks of growth, and washed and stored in methanol, or freeze-dried.

\section{Methods}

Analytical methods. The analytical methods employed were those described by Manners \& Ryley (1952, 1955), with the following exceptions. Paper chromatograms were developed with ethyl acetate-pyridine-water (10:4:3, by vol.) (solvent 1), butan-1-ol-pyridine-water (6:4:3, by vol.) (solvent 2) or butan-2-one-acetic acid-water, saturated with boric acid (9:1:1, by vol.) (solvent 3). Chromatographic mobilities are expressed relative to that of $D$ glucose $\left(R_{\mathrm{G}} 1 \cdot 00\right)$. The formaldehyde liberated on periodate oxidation was measured with either a phenylhydrazineferricyanide reagent (Hough, Powell \& Woods, 1956) or a chromotropic acid reagent (MacFadyen, Watkins \& Anderson, 1945). The reduction of periodate was determined either volumetrically (Fleury \& Lange, 1933) or spectrophotometrically (Aspinall \& Ferrier, 1957).

Mannose in the presence of glucose was determined from the decrease in reducing power caused by treatment of the mixed sugars with glucose oxidase. Solutions of glucose (about $20 \mathrm{mg}$.) and mannose (about $5 \mathrm{mg}$.) were mixed and incubated at $35^{\circ}$ with glucose-oxidase solution $(75 \mathrm{mg}$. of Takamine DeO enzyme preparation in $5 \mathrm{ml}$. of water) in a total volume of $25 \mathrm{ml}$. Samples $(6 \mathrm{ml}$.) were removed at intervals, heated $\left(3 \mathrm{~min}\right.$. at $\left.100^{\circ}\right)$, cooled and centrifuged. The reducing-sugar content of $2 \mathrm{ml}$. portions was determined, and the results showed that $30 \mathrm{hr}$. incubation was required for the complete oxidation of glucose. When $20.1 \mathrm{mg}$. of glucose and $2.36 \mathrm{mg}$. of mannose were analysed, the observed sugar contents were $20.5 \mathrm{mg}$. of glucose (102\% of theoretical) and $2.26 \mathrm{mg}$. of mannose (96\% of theoretical). The results obtained by this method are regarded as being accurate only to $\pm 5 \%$.

Preparation of polysaccharide alcohols. Polysaccharide (200 mg.) was dissolved or suspended in water $(10 \mathrm{ml}$.) and potassium borohydride (100 mg.) added. After mechanical shaking for $48 \mathrm{hr}$., the excess of borohydride was decomposed with acetic acid, ethanol added and the mixture centrifuged. The polysaccharide alcohols were washed with ethanol and ether, and dried at $60^{\circ}$ over phosphorus pentoxide. The glucose contents (on which the yield of formaldehyde produced on periodate oxidation is calculated) were 
$86 \%$ for leucositol and $95 \%$ for paramylitol, the impurity being inorganic material.

Periodate-oxidation analysis. The general procedure followed was that described by Anderson, Hirst, Manners \& Ross (1958); results are expressed throughout as mol.prop./ anhydroglucose residue. Oxidation of a linear chain of $(1 \rightarrow 3)$-linked glucose residues at $2^{\circ}$ will liberate 1 mol.prop. of formic acid from any non-reducing terminal groups or other triol groups. At the reducing group an intermediary formyl ester is formed, which is hydrolysed only very slowly, so that formic acid and formaldehyde are released after days rather than hours. At room temperature (18$20^{\circ}$ ) the ester is slowly hydrolysed with the eventual formation of 2 mol.prop. of formic acid and 1 mol.prop. of formaldehyde. At this temperature some 'over-oxidation' (see below) is apparent, but the initial production of formic acid can be obtained by extrapolation of the linear portion of the graph of formic acid production against time to zero time.

The degree of polymerization (i.e. the number of glucose residues/molecule) can be calculated from the weight of polysaccharide producing 1 mole of formaldehyde, or the weight of polysaccharide alcohol yielding 2 moles of formaldehyde.

Periodate oxidations were also carried out at pH 8 as described by Hough \& Perry (1956). In these experiments a $(1 \rightarrow 3)$-linked glucosan is oxidized, in a stepwise manner from the reducing group, with the liberation of 1 mol.prop. of formaldehyde/glucose residue. The 'over-oxidation' is arrested by $(1 \rightarrow 6)$-linked glucose residues or other structural features that do not lead to the formation of intermediary malonaldehyde derivatives. (Over-oxidation can be regarded as the production of formic acid and formaldehyde, and the reduction of periodate, by oxidative reactions not involving the cleavage of $\alpha$-glycol groups.)

For the formaldehyde determinations, samples $(1 \mathrm{ml}$. were withdrawn from the oxidation mixtures and M-sodium sulphite $(1 \mathrm{ml}$.) and ethanol $(5 \mathrm{ml}$.) added to precipitate polysaccharide. Samples $(1 \mathrm{ml}$.) of the supernatant solution were then analysed by the chromotropic acid method. This modification was devised by Parrish (1959) to decrease interference between carbohydrate and sulphuric acid.

\section{RESULTS}

\section{Examination of the polysaccharides from Ochromonas malhamensis}

Isolation of leucosin preparation I. The crude polysaccharide preparation was extracted with water $(1.5 \%$, $\mathrm{w} / \mathrm{v}$ ) for $1 \mathrm{hr}$., at room temperature, and insoluble material removed by centrifuging. Ethanol (3 vol.) was added to the extract, the precipitate redissolved in water, the solution centrifuged and polysaccharide material reprecipitated with ethanol. The purification was repeated to give a buff material that contained: anhydrohexose (as glucose), $79 \%$; ash, $3.4 \%$; protein, $13 \%$. An acid hydrolysate contained glucose, small amounts of galactose and mannose, and a trace of xylose (by paper chromatography).

The material was partly deproteinized by 12 treatments with 0.1M-sodium chloride and toluene (Anderson \& Greenwood, 1955), the protein content being decreased from 13.1 to $5.6 \%$.

A portion of the product (4.0 g.) was dissolved in water
$(200 \mathrm{ml}$.$) , and 3 \%(\mathrm{w} / \mathrm{v})$ Cetavlon (cetyltrimethylammonium bromide) solution (100 ml.) was added slowly with stirring (cf. Barker, Stacey \& Zweifel, 1957). A brown precipitate was removed, and ethanol (3 vol.) was added to the supernatant solution. Cetavlon was removed from the precipitate by a further six ethanol precipitations to yield a white powder (2.3 g.) referred to below as 'leucosin preparation I'.

Analysis of leucosin preparation I. Paperchromatographic examination of a total acid hydrolysate showed proportions of glucose, mannose and xylose similar to those present before precipitation with Cetavlon, but a decrease in the amount of galactose. Leucosin preparation I had $[\alpha]_{\mathrm{D}}+15^{\circ}$ (c 0.3 in water), and contained: anhydrohexose (as glucose), 90\%; ash, 1.9\%; protein, 4.5\%.

A sample (10 mg.) was partly hydrolysed by heating at $100^{\circ}$ in $0.5 \mathrm{~N}$-sulphuric acid for $1.5 \mathrm{hr}$. Paper chromatography showed the presence of the four monosaccharides, and of sugars having the same mobilities as authentic samples of laminaribiose, -triose and -tetraose, together with a fourth sugar. The $R_{\mathrm{G}}$ values in solvent 2 were: $0.81,0.56$, 0.38 and 0.28 ; Peat, Whelan \& Lawley (1958) quote values of $0.80,0.57,0.40$ and 0.28 for the laminaribiose, -triose, -tetraose and -pentaose respectively.

Incubation of a sample (10 mg.) with $10 \mathrm{mg}$. of an endo- $\beta$-glucosidase preparation from Cladophora rupestris [prepared by Dr W. A. M. Duncan (see Duncan, Manners \& Ross, 1956)] in $0.5 \mathrm{ml}$. of water for $48 \mathrm{hr}$. resulted in the formation of glucose, mannose, laminari-biose, -triose, -tetraose and higher sugars. The enzyme preparation liberated a similar series of oligosaccharides from laminarin. Incubation with almond emulsin (an exo- $\beta$ glucosidase), prepared by Dr F. B. Anderson, gave only a small amount of glucose.

Purification of leucosin preparation I. Attempts to remove the mannose-containing polysaccharide by copper-complexing or by precipitation with Cetavlon at various $\mathrm{pH}$ values were not successful. However, small-scale experiments showed that some fractionation occurred on precipitation with acetone.

Leucosin preparation I (2.0 g.) was dissolved in water (700 ml.) containing $\mathbf{0 . 5} \mathrm{g}$. of ammonium acetate. Acetone (800 ml.) was added slowly with stirring, and the precipitate $(\mathrm{I} a)$ was collected by centrifuging, dissolved in water, reprecipitated and dried. Acetone $(1000 \mathrm{ml}$.) was then added to the supernatant solution to yield a second fraction $(\mathrm{I} b)$, and from the remaining solution a third fraction ( $\mathrm{I} c$ ) was obtained after the addition of a further $1000 \mathrm{ml}$. of acetone. A portion of each fraction was hydrolysed and examined by paper chromatography. The yields of the fractions, and the constituent sugars, were as follows: Ia (445 mg.), galactose $(+++)$, glucose $(++)$, mannose $(++)$; Ib (771 mg.), glucose $(+++)$, mannose $(+)$, 
galactose ( \pm ); Ic (723 mg.), glucose $(++)$, mannose $(+)$, xylose $( \pm)$.

Fraction Ic was redissolved in water $(200 \mathrm{ml}$.) and precipitated with acetone $(600 \mathrm{ml}$.) to yield a polysaccharide (Id) (400 mg.) that was free from xylose.

The glucose and mannose contents were determined by the glucose-oxidase method to be 71 and $11 \%$ respectively for fraction $1 b$, and 78 and $11 \%$ respectively for fraction $1 d$. The fractions were combined and dialysed for 3 days against distilled water (a control experiment had shown that $98 \%$ of the polysaccharide was retained on dialysis). A slight brown precipitate was removed by centrifuging, followed by filtration through an asbestos pad, and ethanol (3 vol.) was then added to give 'leucosin preparation II' (770 mg.).

Analysis of leucosin preparation II. By the glucose-oxidase method, the glucose and mannose contents were 85 and $12 \%$ respectively. The reducing power measured against a laminaribiose standard corresponded to the apparent presence of 1 reducing group/63 hexose residues, indicating polysaccharide rather than oligosaccharide material. Leucosin preparation II had $[\alpha]_{\mathrm{D}}+10.8^{\circ}$ (c 1.0 in water).

Leucosin preparation II (249.0 mg.) was dissolved in water $(25 \mathrm{ml}$.). A portion of this solution $(20 \mathrm{ml}$.) was cooled to $2^{\circ}, 0.3 \mathrm{M}$-sodium metaperiodate solution (4 ml.) was added, and the mixture was diluted to $100 \mathrm{ml}$. with water. Samples $(10 \mathrm{ml}$.) were withdrawn at intervals for measurement of formic acid, which amounted to 0.058 , 0.080 and 0.085 mol.prop. after 2,7 and 9 days respectively. The average value of the formic acid content after 7-9 days corresponds to 1 molecule/ 12 hexose residues. The reduction of periodate, from analysis of $5 \mathrm{ml}$. samples, corresponded to $0 \cdot 16$ and 0.18 mol.prop. after 7 and 9 days respectively. The production of formaldehyde, as measured by the ferricyanide method, was constant at 0.029 mol.prop. between 7 and 9 days, and corresponded to 1 molecule/35 hexose residues.

In a second experiment in which $195 \cdot 1 \mathrm{mg}$. of leucosin preparation II was oxidized at $2^{\circ}$, for 6 days, the reduction of periodate was $0.17 \mathrm{~mol}$.prop. and the production of formic acid $0.078 \mathrm{~mol}$.prop. After a further $48 \mathrm{hr}$. at $20^{\circ}$, these values had increased to only 0.18 and 0.081 mol.prop. respectively. The average formic acid production corresponded to 1 molecule/12.6 hexose residues.

Leucosin preparation II (9.7 mg.) was also oxidized at $35^{\circ}$ and $\mathrm{pH} 8$ with sodium metaperiodate. [The reagents were $0.3 \mathrm{M}$-sodium metaperiodate $(2 \mathrm{ml}$.), $0.1 \mathrm{M}$-sodium phosphate buffer $(12 \mathrm{ml}$.) and water to $25 \mathrm{ml}$.] The production of formaldehyde was constant after $18 \mathrm{hr}$. (analysis was continued for 4 days), and amounted to 0.53 mol.prop.

Isolation of leucosin preparation III. A second sample of crude polysaccharide preparation was extracted with water, precipitated with ethanol, and treated with Cetavlon (as described above), to yield a white powder (5.6 g.). This was dissolved in water (1 l.) containing ammonium acetate $(0.5 \mathrm{~g}$.$) ,$ and three fractions were obtained by precipitation with acetone, as follows: $1200 \mathrm{ml}$. of acetone gave fraction A (1.91 g.), a further $1600 \mathrm{ml}$. of acetone gave fraction $B(2.90 \mathrm{~g}$.), and, finally, $3500 \mathrm{ml}$. of acetone gave fraction $\mathrm{C}(0.31 \mathrm{~g}$.).

By paper chromatography, fraction A contained glucose $(++t)$, galactose $(t)$ and mannose $( \pm)$, fraction $B$ contained glucose $(+++)$, galactose $( \pm)$ and mannose $( \pm)$, and fraction $\mathrm{C}$ contained glucose $(++)$, mannose $(+)$ and xylose $( \pm)$.

Fraction B (2.0 g.) was dissolved in water $(500 \mathrm{ml}$.$) , and acetone (750 \mathrm{ml}$.) was added to give fraction B $1(0.23 \mathrm{~g}$.$) . The addition of further$ acetone $(1500 \mathrm{ml}$.) to the supernatant solution gave fraction B2 (1.24 g.). The latter was purified by dialysis, filtration through an asbestos pad and precipitation with ethanol to yield a white powder (1.05 g.), referred to below as 'leucosin preparation III'.

Characterization of the sugars in fraction $A$. A sample $(0 \cdot 7 \mathrm{~g}$.) was hydrolysed with $2 \mathrm{~N}$-sulphuric acid $\left(70 \mathrm{ml}\right.$.) at $98^{\circ}$ for $2 \mathrm{hr}$., neutralized (with barium carbonate) and the volume decreased to $5 \mathrm{ml}$. Part of the hydrolysate (4 ml.) was applied to a column of Dowex 50W (X8; 200-400 mesh; $\mathrm{Ba}^{2+}$ form) resin and the monosaccharides were eluted with distilled water (Jones \& Wall, 1960). Fractions (3-4 ml.) were collected at intervals, and analysed by paper chromatography. Fractions 3034 contained glucose, 36-40 contained glucose and galactose, 42 contained these sugars and xylose, 44 also contained mannose, and 46-47 contained the three hexoses. Concentration of fractions 29-34 gave D-glucose, characterized as the pentaacetate (m.p. and mixed m.p. $130-131^{\circ}$ ); from fractions 39-41, D-galactose was obtained as the crystalline 1-methyl-1-phenylhydrazone (m.p. and mixed m.p. $180-183^{\circ}$ ). Fractions 44-50 were applied to Whatman $3 \mathrm{MM}$ paper, and the D-mannose was separated, eluted and characterized as the phenylhydrazone (m.p. and mixed m.p. $190-193^{\circ}$ ).

The molar proportion of the three hexoses was determined by the method of Wilson (1959). From paper chromatograms developed with solvent 1 , the molar ratio of glucose to galactose was $86 \cdot 6: 13 \cdot 4$, and from chromatograms developed in solvent 3 , which give an improved separation of mannose from the other hexoses, the following composition was obtained: glucose, $86 \%$; galactose, $13 \%$; mannose, $1 \%$.

Analysis of leucosin preparation III. The polysaccharide had $[\alpha]_{D}+9 \cdot 1^{\circ}$ (c 0.4 in water), and a reducing power equivalent to an apparent degree of polymerization of 63 , indicating a polysaccharide rather than an oligosaccharide nature. On hydrolysis with acid, it gave glucose and no other sugar (by paper chromatography). By cuprimetric titration, the glucose content was $91 \%$, and the analytical results are based on this value. Further examination of an acid hydrolysate showed: $(a)$ that 
the sugar was destroyed by D-glucose oxidase; (b) that non-reducing carbohydrates, e.g. mannitol and sorbitol, were absent. Under similar conditions, the presence of mannitol in an acid hydrolysate of laminarin could be readily detected.

Leucosin preparation III (184 mg. in $20 \mathrm{ml}$. of water) was oxidized with a mixture of $0.3 \mathrm{M}$-sodium metaperiodate $\left(20 \mathrm{ml}\right.$.) and $5 \%(\mathrm{w} / \mathrm{v})$ potassium chloride $\left(15 \mathrm{ml}\right.$.) at $20^{\circ}$. The production of formic acid after 3, 5, 7 and 9 days amounted to $0.079,0.091,0.095$ and 0.100 mol.prop. respectively. Extrapolation of the results indicated that, in the initial oxidation, 0.078 mol.prop. was liberated, corresponding to 1 molecule/12.8 glucose residues.

Leucosin preparation III (196 mg.) was also oxidized with $0.3 \mathrm{M}$-sodium metaperiodate solution $(8 \mathrm{ml}$.) in a total volume of $100 \mathrm{ml}$. at $20^{\circ}$. The reduction of periodate was 0.15 and $0.17 \mathrm{~mol}$.prop. after 24 and $48 \mathrm{hr}$. respectively, and the initial production of formic acid corresponded to 1 molecule/12.8 glucose residues.

Oxidation of leucosin preparation III (11.5 mg.) at pH 8 in a total volume of $25 \mathrm{ml}$. gave the following production of formaldehyde: $0.39,0.44,0.50,0.50$ and 0.49 mol.prop. after $21,25,30,72$ and $168 \mathrm{hr}$. respectively. Under similar conditions, laminarin gave 0.54 mol.prop. of formaldehyde.

Leucosin preparation III (40.4 mg.) and leucositol prepared from it $(30.2 \mathrm{mg}$.) were each dissolved in water $(9 \mathrm{ml}$.) and oxidized with $0.3 \mathrm{M}$-sodium metaperiodate solution (1 ml.) at $17^{\circ}$. The final production of formaldehyde corresponded to degrees of polymerization of about 35 and 33 glucose residues respectively (see Table 1 ). At $2^{\circ}$, leucosin failed to give a significant amount of formaldehyde within $1 \mathrm{hr}$., showing the absence of mannitol-terminated chains of glucose residues (cf. Anderson et al. 1958).

Leucosin preparation III (20.0 mg.) was dissolved in $0.05 \mathrm{M}$-sodium citrate buffer, $\mathrm{pH} 4.8$ (5 ml.), and Rhizopus arrhizus enzyme preparation (4 mg.) was added. This preparation showed laminarinase but not cellodextrinase activity (see Cunningham \& Manners, 1961). The digest was incubated at $37^{\circ}$, when the apparent percentage conversion into glucose after $3,21,46$ and $96 \mathrm{hr}$. was 52, 66, 72 and 75 respectively. Paper chromatography (with solvent 2) showed the presence of glucose and laminaribiose, and a trace of an oligosaccharide with $R_{\mathrm{G}} \mathbf{0 . 5 3}$. In a control digest with laminarin, the same sugars were produced and about $71 \%$ of the polysaccharide was converted into reducing sugar (as glucose).

The infrared-absorption spectrum of leucosin preparation III was examined in Nujol with a PerkinElmer Infracord spectrophotometer. The spectrum showed an absorption band at $890 \mathrm{~cm} .^{-1}$, and was almost identical with that of laminarin, and with that of a sample of chrysolaminarin provided by Dr E. E. Percival (cf. Beattie, Hirst \& Percival, 1961).

Smith degradation of leucosin preparation III. Leucosin preparation III (99 mg.) was oxidized with $0.3 \mathrm{M}$-sodium metaperiodate solution (3 ml.) in a total volume of $25 \mathrm{ml}$. for $48 \mathrm{hr}$. at $18^{\circ}$. Excess of periodate was destroyed by the addition of $12.6 \%(\mathrm{w} / \mathrm{v})$ sodium sulphite solution $(12.5 \mathrm{ml}$.$) ,$ and, after $30 \mathrm{~min}$., potassium borohydride (100 $\mathrm{mg}$.) was added. After $40 \mathrm{hr}$. at $18^{\circ}$, the excess of borohydride was decomposed by the careful addition of acetic acid to give pH 6-7. The solution was made 0.1 N with respect to sulphuric acid and maintained at $18^{\circ}$ for $24 \mathrm{hr}$. to effect partial hydrolysis of the polyalcohol. (The general conditions are similar to those employed in parallel studies on laminarin by Smith \& Unrau, 1959.) The hydrolysate was neutralized with sodium hydroxide solution (to $\mathrm{pH} 7$ ) and dialysed for $48 \mathrm{hr}$. against five successive changes of distilled water (3 l. each).

The non-diffusible material was recovered by freezedrying. The yield was $114 \mathrm{mg}$; the glucose content was $79 \%$, equivalent to a $91 \%$ recovery of polysaccharide. The impurity was inorganic material.

Undiffusible polysaccharide (36.3 mg., based on glucose content) was oxidized with 2 mM-sodium metaperiodate $\left(5 \mathrm{ml}\right.$.) at $2^{\circ}$ for $24 \mathrm{hr}$. Samples $(1 \mathrm{ml}$.) were removed at intervals, and treated with $12.6 \%(\mathrm{w} / \mathrm{v})$ sodium sulphite solution $(0.5 \mathrm{ml}$.) and ethanol $(6 \mathrm{ml}$.) to remove respectively excess of periodate and polysaccharide, and the formaldehyde contents of the supernatant solutions were measured by the chromotropic acid procedure. The production of formaldehyde after $2,5.5$ and $24 \mathrm{hr}$. amounted to 0.0062 , 0.0059 and 0.0058 mol.prop. respectively. A molecule containing only one internal $(1 \rightarrow 6)$-glucosidic linkage would yield about 0.03 mol.prop. of formaldehyde.

Table 1. Production of formaldehyde by the periodate oxidation of leucosin, paramylon and their respective alcohols

The oxidation conditions are given in the text. The formaldehyde results are expressed as mol.prop./glucose residue.

\begin{tabular}{|c|c|c|c|c|c|c|c|c|}
\hline \multirow[b]{2}{*}{$\begin{array}{l}\text { Time of } \\
\text { oxid- } \\
\text { ation } \\
\text { (days) }\end{array}$} & \multicolumn{2}{|c|}{ Leucosin } & \multicolumn{2}{|c|}{ Leucositol } & \multicolumn{2}{|c|}{ Paramylon } & \multicolumn{2}{|c|}{ Paramylitol } \\
\hline & $\begin{array}{c}\text { Formaldehyde } \\
\text { release }\end{array}$ & $\begin{array}{c}\text { Degree of } \\
\text { poly- } \\
\text { merization }\end{array}$ & $\begin{array}{c}\text { Formaldehyde } \\
\text { release }\end{array}$ & $\begin{array}{c}\text { Degree of } \\
\text { poly- } \\
\text { merization }\end{array}$ & $\begin{array}{c}\text { Formaldehyde } \\
\text { release }\end{array}$ & $\begin{array}{c}\text { Degree of } \\
\text { poly- } \\
\text { merization }\end{array}$ & $\begin{array}{c}\text { Formaldehyde } \\
\text { release }\end{array}$ & $\begin{array}{c}\text { Degree of } \\
\text { poly- } \\
\text { merization }\end{array}$ \\
\hline $\begin{array}{r}1 \\
5 \\
11 \\
18 \\
22 \\
29\end{array}$ & $\begin{array}{l}0.0069 \\
0.0169 \\
0.0215 \\
0.0267 \\
0.0272 \\
0.0283\end{array}$ & $\begin{array}{r}145 \\
59 \\
47 \\
37 \\
37 \\
35\end{array}$ & $\begin{array}{l}0.0281 \\
0.0418 \\
0.0519 \\
0.0576 \\
0.0590 \\
0.0614\end{array}$ & $\begin{array}{l}71 \\
48 \\
38 \\
\mathbf{3 5} \\
\mathbf{3 4} \\
\mathbf{3 3}\end{array}$ & $\begin{array}{l}0.0031 \\
0.0062 \\
0.0097 \\
0.0128 \\
0.0130 \\
0.0142\end{array}$ & $\begin{array}{r}320 \\
161 \\
103 \\
78 \\
77 \\
71\end{array}$ & $\begin{array}{l}0.0057 \\
0.0096 \\
0.0167 \\
0.0189 \\
0.0213 \\
0.0225^{*}\end{array}$ & $\begin{array}{c}370 \\
208 \\
121 \\
106 \\
94 \\
89^{*}\end{array}$ \\
\hline
\end{tabular}

* 0.0228 and 88 after 35 days. 
Preparation of leucosin acetate. Fraction B (see above) (500 mg.) was dispersed in formamide $(5 \mathrm{ml}$.), and treated with acetic anhydride $(4 \mathrm{ml}$.) and pyridine $(10 \mathrm{ml}$.). The mixture was shaken in the dark for 4 days and then poured into ice-water $(500 \mathrm{ml}$.) with stirring. The precipitated acetate was washed several times with water, filtered and dried. It was purified by solution in chloroform and precipitation with light petroleum (b.p. $80-100^{\circ}$ ). The yield was $480 \mathrm{mg}$; t the acetyl content was $41.2 \%$; $[\alpha]_{\mathrm{D}}-59.3^{\circ}$ (c 0.9 in chloroform).

\section{Examination of the polysaccharide from Peranema trichophorum}

Isolation of paramylon. In preliminary experiments, extraction of the cells with water or dilute sodium hydroxide solution gave low yields of an impure glucose-containing polysaccharide. The procedure of Clarke \& Stone (1960) was therefore adopted. The cells from 54 l. of culture medium were suspended in water, and disrupted by ultrasonic vibrations. Fatty material was discarded, and the cell debris was washed with alcohol and ether and dried. The yield was $1.8 \mathrm{~g}$. This material was incubated with trypsin (95 mg. of a Nutritional Biochemicals Corp. preparation in $50 \mathrm{ml}$. of $0.1 \mathrm{M}$-sodium phosphate buffer, $\mathrm{pH} 7 \cdot 6$ ) at $40^{\circ}$ for $40 \mathrm{hr}$., the mixture centrifuged, and the residue extracted twice with saturated urea solution and washed with water. The remaining denatured protein was then removed by shaking the off-white material for $60 \mathrm{~min}$. with chloroform $(50 \mathrm{ml}$.$) , water (130 \mathrm{ml}$.$) and pentanol (20 \mathrm{ml}$.$) , and$ separating the chloroform-protein gel by centrifuging. Ethanol (3 vol.) was added to the aqueous phase, and the white particles of paramylon were collected, washed with ethanol and then ether, and air-dried. The yield was $1.06 \mathrm{~g}$. (59\% of the dried cell material).

Examination of paramylon. Paramylon was insoluble in water, $\mathrm{N}$-sodium hydroxide and $2 \mathrm{~N}$ sulphuric acid. For acid hydrolysis $20 \mathrm{mg}$. was heated with $90 \%$ formic acid solution $\left(2 \mathrm{ml}\right.$.) at $98^{\circ}$ for $2 \mathrm{hr}$., and then $2 \mathrm{~N}$-sulphuric acid $(4 \mathrm{ml}$.) was added and heating continued for a further $3 \mathrm{hr}$. The neutralized hydrolysate contained only glucose, and, by cuprimetric titration, the content was $97 \%$. A partial acid hydrolysate contained glucose and four oligosaccharides with the $R_{\mathrm{G}}$ values of laminarisaccharides. Treatment of this hydrolysate with glucose oxidase caused the destruction of glucose and the formation of gluconic acid (detected by paper chromatography).

Paramylon dissolved slowly in cold $5 \mathrm{~N}$-sodium hydroxide solution $\left([\alpha]_{\mathrm{D}}+16^{\circ} ; \mathrm{c} 1 \cdot 2\right)$. A suspension (59 mg.) in $15 \mathrm{~mm}$ sodium metaperiodate $\left(10 \mathrm{ml}\right.$.) was kept at $27^{\circ}$ for $72 \mathrm{hr}$. The reduction of periodate was 0.03 mol.prop., whereas under the same conditions laminarin reduced 0.30 mol.prop.

Paramylon $(38.0 \mathrm{mg}$.) and paramylitol prepared from it $(26.7 \mathrm{mg}$.) were each suspended in water $(9 \mathrm{ml}$.) and oxidized with $0 \cdot 3 \mathrm{M}$-sodium metaperiodate solution $\left(1 \mathrm{ml}\right.$.) at $17^{\circ}$. The results (Table 1) show that the degree of polymerization is about 80 glucose residues. At $2^{\circ}$ there was no significant release of formaldehyde from paramylon, indicating a similarity to leucosin and a difference from laminarin. On periodate oxidation at $\mathrm{pH} 8$, the production of formaldehyde after $5,19,25$ and 30 days was $0.22,0.31,0.30$, $0 \cdot 29$ mol.prop. respectively.

Paramylon (20 mg.) was dissolved with difficulty in $2 \mathrm{~N}$-sodium hydroxide solution, neutralized, and pH 4.8 buffer and Rhizopus preparation were added as for leucosin III (see above). After incubation at $37^{\circ}$ for 24 and $48 \mathrm{hr}$., the presence of glucose and laminaribiose was shown by paper chromatography. Since a large part of the paramylon was not in solution, cuprimetric titrations were not carried out. Samples of chrysolaminarin and the glucosan from Euglena gracilis (prepared by the method of Clarke \& Stone, 1960) on incubation with the Rhizopus preparation were rapidly hydrolysed (within $1.5 \mathrm{hr}$.) to glucose and laminaribiose. Laminaritriose was also present in the chrysolaminarin digest.

In a Nujol mull, the paramylon gave an infraredabsorption spectrum almost identical with that of laminarin, showing an absorption band at $890 \mathrm{~cm}^{-1}$.

\section{DISCUSSION}

The present investigation shows that the flagellate Ochromonas malhamensis synthesizes a mixture of polysaccharides including polymers of D-glucose, D-galactose and D-mannose. By precipitation with Cetavlon and with acetone a pure glucosan (leucosin) can be obtained, which contains $\beta$ glucosidic linkages, as shown by the low specific rotation, hydrolysis by $\beta$-glucosidase preparations and the infrared-absorption spectrum. The presence of $(1 \rightarrow 3)$-linkages is indicated by the resistance of the polysaccharide to periodate oxidation, the formation of laminarisaccharides on partial hydrolysis with acid, and the production of glucose and laminaribiose on enzymic degradation.

On periodate oxidation with either sodium metaperiodate at $2^{\circ}$ or with potassium metaperiodate at 18-20 $0^{\circ}$, the production of formic acid corresponded to the presence of one 'triol' group (i.e. non-reducing end group, or internal ( $1 \rightarrow 6)$-glucosidic linkage) per 12-13 glucose residues. Since the degree of polymerization is approximately 34 , the molecules each contain on the average three 'triol' groups which may be present as (a) non-reducing end groups, implying the presence of two branch points/ molecule, (b) two internal ( $1 \rightarrow 6$ )-glucosidic linkages/ molecule or $(c)$ one branch point and one internal $(1 \rightarrow 6)$-glucosidic linkage/molecule. Structures of the $(b)$ and $(c)$ type exist in yeast glucan (Peat, Whelan \& Edwards, 1958) and chrysolaminarin (Beattie et al. 1961).

It is unfortunate that the solution of this problem by methylation or partial acid hydrolysis requires larger quantities of leucosin than were available.

Bioch. 1963, 88 
Nevertheless, additional periodate-oxidation experiments indicate that inter-chain linkages rather than internal $(1 \rightarrow 6)$-glucosidic linkages are most probably present (Scheme 1).

Leucosin preparation III was subjected to the Smith degradation procedure (see Smith \& Montgomery, 1959) involving periodate oxidation, borohydride reduction and partial acid hydrolysis. The residual polysaccharide was non-diffusible, and, on further oxidation with a dilute solution of sodium metaperiodate, the yield of formaldehyde was only one-fifth of that expected from structure $(c)$, and one-tenth of that from structure $(b)$. If leucosin contained internal $(1 \rightarrow 6)$-glucosidic linkages, then the degradation procedure would yield linear chains of degree of polymerization 12-17. Since laminarin preparations with a degree of polymerization 20-25 are diffusible (W. D. Annan \& D. J. Manners, unpublished work), any linear chains derived from leucosin should also be diffusible.

Moreover, partial hydrolysis of the leucosin polyalcohol would yield a $1-O$-substituted glycerol (Scheme 1) that on controlled periodate oxidation would yield 1 mole of formaldehyde/molecule. The observed yield was only $0.204 \mathrm{~mole} / \mathrm{molecule}$, whereas in a control experiment with 1-O- $\beta$ glucosylmannitol 0.96 mole of formaldehyde/molecule was liberated. The small yield of formaldehyde could arise from a limited reaction at the residue of the original reducing group.

The fact that leucosin is not solely a linear polymer of $\beta$-(1 $\rightarrow 3)$-linked $D$-glucose residues is also shown by the production of $0.5 \mathrm{~mol}$.prop. of formaldehyde on overoxidation with periodate at pH 8. Although this value is similar to that obtained with laminarin (Anderson et al. 1958), the reasons for this are different. In laminarin, about $50 \%$ of the polysaccharide chains are terminated by a 1.O-linked mannitol residue, and are therefore resistant to overoxidation. Mannitol is not a constituent of leucosin, and the observed yield of formaldehyde is consistent with a slightly branched structure.

The reserve carbohydrate of Peranema trichophorum (paramylon) resembles leucosin in several respects, but differs significantly in its solubility properties and in molecular size (degree of polymerization about 80 ). The relative insolubility of paramylon prevented a complete study of the extent of hydrolysis by the Rhizopus enzyme preparation and the extent of overoxidation by periodate (the yield of $0.3 \mathrm{~mol}$.prop. of formaldehyde shows only the existence of adjacent $(1 \rightarrow 3)$ linked glucose residues near to the reducing end of polysaccharide chain). The relative insolubility of long linear chains of $\beta$-(1 $(\rightarrow 3)$-linked glucose residues has also been noted with pachyman (Warsi \&

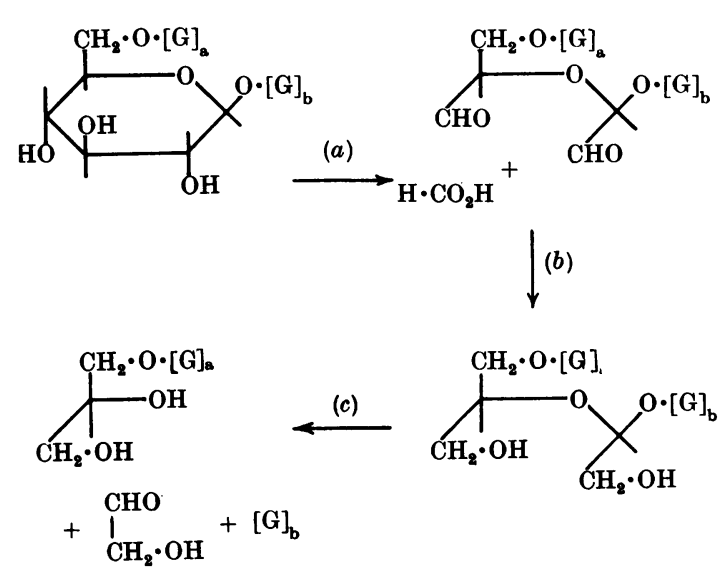

Scheme 1. Degradation of an internal $(1 \rightarrow 6)$-linked D-glucose residue by $(a)$ periodate oxidation followed by $(b)$ borohydride reduction and (c) partial acid hydrolysis. $[G]_{\mathrm{a}}$ or $[\mathrm{G}]_{\mathrm{b}}$, chain of $(1 \rightarrow 3)$-linked glucose residues.

Table 2. Properties of some $\beta-(1 \rightarrow 3)$-glucosans

Property
$[\alpha]_{\mathrm{v}}$ (water) $\left({ }^{\circ}\right)$
$[\alpha]_{\mathrm{D}}(\mathrm{NaOH})\left(^{\circ}\right)$
Acetate, $[\alpha]_{\mathrm{D}}\left(\right.$ in chloroform) $\left(^{\circ}\right)$
Infrared-absorption spectrum
(absorption peak) $\left(\mathrm{cm} .^{-1}\right)$
Periodate oxidation:
at $\mathrm{pH} 5$, reduction
(molecule/anhydroglucose
residue)
at pH 8, production of
formaldehyde (molecule/
anhydroglucose residue)
Hydrolysis by Rhizopus
preparation

Laminarin

$$
-9
$$$$
+9
$$$$
\begin{array}{r}
+9 \\
-60
\end{array}
$$$$
890
$$$$
\mathbf{0 . 3 0}
$$

0.53

Chrysolaminarin*

-6
.
8

890

$\mathbf{0 \cdot 3 0}$

$0 \cdot 61$

$+$
Leucosin
$+10$
$-\dot{59}$
890

$0 \cdot 17$

$\mathbf{0} \cdot 53$
Euglena gracilis polysaccharide $\dagger$ $+28$ 890

0.02

* See Beattie et al. (1961). † See Clarke \& Stone (1960). 
Whelan, 1957) and the paramylon from Euglena gracilis (Clarke \& Stone, 1960).

The pattern of polysaccharide synthesis in Ochromonas is more complex than in Peranema since the former contains appreciable quantities of D-galactose and D-mannose-containing polysaccharide.

The results described in the present paper, together with those of Clarke \& Stone (1960), provide the first evidence for the presence of $\beta$ - $(1 \rightarrow 3)$-linked glucose polymers in the protozoal group. This finding is of considerable biochemical interest since these linkages have hitherto been found only in polysaccharides isolated from yeast, marine algae, the fungus Poria cocos Wolf and callose-type membranes from certain higher plants (see Table 2 and, for example, Peat, Whelan \& Edwards, 1958; Anderson etal. 1958; Warsi \& Whelan, 1957 ; Aspinall \& Kessler, 1957).

\section{SUMMARY}

1. Aqueous extraction of the flagellate Ochromonas malhamensis yields a mixture of polysaccharides composed of D-glucose, D-galactose and D-mannose.

2. Acetone fractionation of the mixture gave a polysaccharide (leucosin) composed of $\beta-(1 \rightarrow 3)$ linked D-glucose residues.

3. Periodate-oxidation studies show that leucosin has a degree of polymerization of about 34, and probably has a slightly branched structure.

4. The reserve polysaccharide of Peranema trichophorum (paramylon) also contains $\beta-(1 \rightarrow 3)$ linked $D$-glucose residues. It differs from leucosin in molecular size (degree of polymerization about 80) and in being water-insoluble.

We thank Professor E. L. Hirst, C.B.E., F.R.S., for his interest in this work, which was supported by maintenance allowances from the Department of Scientific and Industrial Research (to A.R.A., W.L.C. and J.R.S.).

\section{REFERENCES}

Anderson, D. M. W. \& Greenwood, C. T. (1955). J. Sci. Fd Agric. 6, 587.
Anderson, F. B., Hirst, E. L., Manners, D. J. \& Ross, A. G. (1958). J. chem. Soc. p. 3233.

Archibald, A. R., Hirst, E. L., Manners, D. J. \& Ryley, J. F. (1960). J. chem. Soc. p. 556.

Archibald, A. R., Manners, D. J. \& Ryley, J. F. (1958). Chem. \& Ind. p. 1516.

Aspinall, G. O. \& Ferrier, R. J. (1957). Chem. \& Ind. p. 1216.

Aspinall, G. O. \& Kessler, G. (1957). Chem. \& Ind. p. 1296.

Barkei, S. A., Stacey, M. \& Zweifel, G. (1957). Chem. \& Ind. p. 330.

Beattie, A., Hirst, E. L. \& Percival, E. (1961). Biochem. J. 79, 531.

Chen, Y. T. (1950). Quart. J. micr. Sci. 91, 279.

Clarke, A. E. \& Stone, B. A. (1960). Biochim. biophys. Acta, 44, 161.

Cunningham, W. L. \& Manners, D. J. (1961). Biochem. J. 80, $42 P$.

Cunningham, W. L., Manners, D. J. \& Ryley, J. F. (1961). Biochem. J. 82, 12 P.

Duncan, W. A. M., Manners, D. J. \& Ross, A. G. (1956). Biochem. J. 63, 44.

Fleury, P. F. \& Lange, J. (1933). J. Pharm. Chim., Paris, 17, 107.

Hough, L. \& Perry, M. B. (1956). Chem. \& Ind. p. 768.

Hough, L., Powell, D. B. \& Woods, B. M. (1956). J. chem. Soc. p. 4799.

Hutner, S. H. \& Provasoli, L. (1951). In Protozoa, vol. 1, p. 47. Ed. by Lwoff, A. New York: Academic Press Inc.

Jones, J. K. N. \& Wall, R. A. (1960). Canad. J. Chem. 38, 2290.

MacFadyen, D. A., Watkins, H. D. \& Anderson, P. R. (1945). J. biol. Chem. 158, 107.

Manners, D. J. \& Ryley, J. F. (1952). Biochem. J. 52, 480.

Manners, D. J. \& Ryley, J. F. (1955). Biochem. J. 59, 369.

Parrish, F. W. (1959). Ph.D. Thesis: University of London.

Peat, S., Whelan, W. J. \& Edwards, T. E. (1958). J. chem. Soc. p. 3862.

Peat, S., Whelan, W. J. \& Lawley, H. G. (1958). J. chem. Soc. p. 724.

Pringsheim, E. G. (1952). Quart. J. micr. Sci. 93, 71.

Ryley, J. F. (1962). Biochem. J. 85, 211.

Smith, F. \& Montgomery, R. (1959). Chemistry of Natural Gums and Mucilages, p. 215. New York: Reinhold Publishing Corp.

Smith, F. \& Unrau, A. M. (1959). Chem. \& Ind. p. 881.

Warsi, S. A. \& Whelan, W. J. (1957). Chem. \& Ind. p. 1573.

Wilson, C. M. (1959). Analyt. Chem. 31, 1199. 